\title{
"OVERPOLICED AND UNDERPROTECTED": 1 RACIALIZED GENDERED VIOLENCE(S) IN TA-NEHISI COATES'S BETWEEN THE WORLD AND ME
}

\author{
"SOBREVIGILADAS Y DESPROTEGIDAS": \\ VIOLENCIA(S) DE GÉNERO RACIALIZADA(S) \\ EN BETWEEN THE WORLD AND ME, \\ DE TA-NEHISI COATES
}

\section{EVA PUYUELO UREÑA}

Universidad de Barcelona

evapuyuelo@ub.edu

\begin{abstract}
Ta-Nehisi Coates's Between the World and Me (2015) evidences the lack of visibility of black women in discourses on racial profiling. Far from tracing a complete representation of the dimensions of racism, Coates presents a masculinized portrayal of its victims, relegating black women to liminal positions even though they are one of the most overpoliced groups in US society, and disregarding the fact that they are also subject to other forms of harassment, such as sexual fondling and other forms of abusive frisking. In the face of this situation, many women have struggled, both from an academic and a political-activist angle, to raise the visibility of the role of black women in contemporary discourses on racism.
\end{abstract}

Keywords: police brutality, racism, gender, silencing, black women.

\section{Resumen}

Con la publicación de la obra de Ta-Nehisi Coates Between the World and Me (2015) se puso de manifiesto un problema que hacía tiempo acechaba a los discursos sobre racismo institucional: ¿dónde estaban las mujeres de color? Lejos de trazar un esbozo fiel de las dimensiones de la discriminación racial, la obra de Coates aboga por una representación masculinizada de las víctimas, relegando a las 


\section{Eva Puyuelo Ureña}

mujeres a posiciones marginales y obviando formas de acoso que ellas, a diferencia de los hombres, son más propensas a experimentar. Frente a esta situación, son muchas las mujeres que han luchado, tanto en el panorama académico como en el político-activista, para visibilizar el rol de las mujeres negras en los discursos actuales sobre racismo.

Palabras clave: brutalidad policial, racismo, género, silenciamiento, mujeres negras.

Ta-Nehisi Coates, author and national correspondent for The Atlantic, published his memoir ${ }^{2}$ Between the World and $M e(2015)$ in the midst of a bitter fight over the impunity with which black people were being locked up and shot down at alarmingly increasing rates (Swaine et al. 2015). According to The Guardian, 2015 turned out to be the deadliest year for victims of color at the hands of law enforcement officers in the US, reaching an all-time high of no less than 1,134 fatal victims (Swaine et al. 2015). The webpage Mapping Police Violence, which was created as a means to denounce both the violent assaults on people of color and the impunity with which they are committed, informs that one out of three victims was unarmed when killed. These numbers had increased compared to the previous year, when Eric Garner, Michael Brown, Laquan McDonald, Tamir Rice, and another 1,127 black individuals had lost their lives in the streets. ${ }^{3}$ The proportion of black individuals murdered in 2014 had been lower than in 2015, but was still disproportionally high. Many authors have contended, taking into consideration the slight differences in annual figures, that assaults on black people should not be taken as surprising or new (Coates 2015; Lowery 2017; Ritchie 2017), as "this conversation is old, and [...] it's the cameras that are new, [i]t's not the violence" (Goodman 2015). As a matter of fact, Ta-Nehisi Coates has been vocal in making public the dangers black individuals are exposed to on a daily basis through his articles and books. He published, in 2014, "The Case for Reparations", a much-debated essay that positioned him amongst the most prominent and prolific authors on racial issues of the moment. "The Case for Reparations" turned out to be the seed from which Between the World and Me sprang almost a year later.

The essay bestowed upon Coates great popularity, practically ensuring that Between the World and Me would also be a phenomenal success. And, as a matter of course, the memoir soon represented a breakthrough in racial studies and literary texts dealing with racial profiling and police brutality. Whilst in "The Case for Reparations" (2014) Coates carries out a diachronic analysis of the ways in which history has contributed to the legitimization of racist practices, in Between the 


\section{Racialized Gendered Violence(s) in Ta-Nehisi Coates}

World and $M e$ he introduces himself as a concerned father warning his son against the dangers of being trapped in the double-bind of a social illegibility that renders black bodies inhuman whilst simultaneously casting them as problems that need to be dealt with (Miller 2016: 16). For him, the "immi/a/nent death" black individuals are subject to, which is contingent upon their being rendered criminals, not only results from policing, but also from other, less visible types of oppression, such as microracist behaviors or intra-racial struggles, let alone the whole system that perpetuates them (Sharpe 2016). He notes, "I feared not just the violence of this world, but the rules designed to protect you from it, the rules that would have you contort your body to address the block, and contort again to be taken seriously by colleagues, and contort it again so as not to give the police a reason" (Coates 2015: 90).

Coates makes it clear that he is writing as an act of self-abnegation, hoping that his own memories help his 15-year-old son, Samori, to be prepared "for facing police harassment and brutality" (Goodman 2015). At the very beginning of the text he remembers the deaths of Eric Garner, choked for selling cigarettes in the street; John Crawford, shot for buying a gun at a local store; or 12-year-old Tamir Rice, shot twice for playing with a toy gun in the street (Coates 2015: 9). But it is Michael Brown's murder that is crucial in the development of the story that he is recounting. ${ }^{4}$ In Ferguson, Missouri, on August 9, 2014, 18-year-old Michael Brown was shot dead by officer Darren Wilson after the former attempted to steal a box of cigarettes from a supermarket. Brown's body was left on the ground for four and a half hours (Lowery 2017: 25), and Wilson was acquitted after testifying that he had fired at Brown six times because of the way "[he] looked up at me and had the most intense aggressive face. The only way I can describe it, it looks like a demon, that's how angry he looked" (in Saucier and Woods 2016: 371). Brown's death epitomizes the monopolization of power that allows black people to be killed with no penalty whatsoever.

Police encounters, however, do not only end up in murders but also in other forms of discriminatory enforcement, such as unwarranted frisking, unjust detentions, or stiff sentences. In 2016, a year after most of the aforementioned deaths took place, black men represented $40.2 \%$ of US prisoners even though they made up only $6.5 \%$ of US society. This, of course, is the result of biased policing, as black people are $21 \%$ more likely to be targeted and wrongly convicted than members of any other racial groups (Duvernay 2016). In fact, most people of color are usually arrested for minor offenses such as drug possession, inebriation, or larceny and, owing to the widespread poverty in many communities of color, they are held for long periods of time in city and county jails because they cannot afford to post bail (Ritchie 2017: 43). 


\section{Eva Puyuelo Ureña}

In Coates's view, the fact that officers are allowed to assault black people with impunity is just an effect of a much larger — and also much less individualizedproblem. ${ }^{5}$ It is, in other words, just the tip of the iceberg, as "the problem with the police is not that they are fascist pigs, but that our country is ruled by majoritarian pigs" (2015: 78). When discussing Darren Wilson's legal acquittal, Coates denounces that the normalization of black bodies being humiliated, frisked, detained, beaten, and ultimately destroyed, is just the result of

men enforcing the whims of our country, correctly interpreting its heritage and legacy. [...] All our phrasing — race relations, racial chasm, racial justice, racial profiling, white privilege, even white supremacy - serves to obscure that racism is a visceral experience, that it dislodges brains, blocks airways, rips muscle, extracts organs, cracks bones, breaks teeth. You must never look away from this. You must always remember that the sociology, history, the economics, the graphs, the repressions all land, with great violence, upon the body. (10)

Taking into account that Between the World and Me addresses in such a direct, heartfelt, and harsh manner all the forms of violence inflicted on black bodies, it comes as no surprise that the book attracted so much public attention. A week after its publication, notes Howard Rambsy II, "more than 100 reviews had been published online in major venues" (2016: 202). Whilst many critics applauded Coates's capacity to articulate in writing the difficult experiences endured nowadays by black individuals in the US (Sandhu 2015), others accused him of adopting an overly disheartening attitude that obscured any possibilities of believing "that freedom or equality will ever be a reality for black people" (Alexander 2015). Of particular interest is the reaction of the black feminist community, which highlighted that as much as Coates's narrative engages in a necessary struggle for the empowerment of black folk, it is also one that excludes the ways in which black women, girls, and gender nonconforming individuals are affected by policing. Months after the publication of the book, authors such as Brit Bennett or Shani O. Hilton openly voiced their dissatisfaction with Coates's gendering of racial profiling, claiming that in his text "the dangers of living in a black female body are mysterious, forever unknowable" (Bennett 2015). Even Patrisse Khan-Cullors, cofounder of Black Lives Matter, ended up admitting that Coates's work reflects a generalized reluctance to consider black women ${ }^{6}$ victims of racial violence (2018).

\section{Targeting Black Men, Silencing Black Women}

The media has played a crucial role in the effacement of black women from discourses on blackness, in particular when they are in some way related to violence (Ritchie 2017: 8-9). In fact, most of the newspapers published after the Ferguson 


\section{Racialized Gendered Violence(s) in Ta-Nehisi Coates}

events reveal a consistency in disregarding black women as targets of policing and racial profiling, turning — and also limiting - attention instead to black men. As an example, The Guardian published in 2017 an essay by Jesmyn Ward entitled "Raising a Black Son in the US" (emphasis added), where she notes that after being told that she was going to have a boy, "[she] cried" to later "lay awake at nights, worrying over the world I was bearing my son into". She then hastens to add that "my son had never taken a breath, and I was already mourning him". Ward's text is not the only one focusing exclusively on the role that men play in narratives on racial profiling. Clint Smith's talk "How to Raise a Black Son in America" (2015), Marc Mauer's Young Men and the Criminal Justice System: A Growing National Problem (1990), or Angela J. Davis's latest book, Policing the Black Man (2017) all suggest that "although black women are routinely killed, raped, and beaten by the police, their experiences are rarely foregrounded in popular understandings of police brutality" (Crenshaw 2015).

The exclusion of black women from narratives in both racial and gender studies has been the object of analysis of many feminist works that have defended the view that this silencing is partly due to the fact that society is built upon whiteness and patriarchy. Amongst other seminal works, All the Women Are White, All the Blacks Are Men, But Some of Us Are Brave (1982), coedited by Akasha Gloria Hull, Patricia Bell Scott, and Barbara Smith, had already argued that black women are affected by a twofold oppression, being black and being women, and urged them to construct a new framework from which to consider black womanhood (xxi). As its title very well suggests, the work argued that discourses on womanhood focus on whiteness, whilst discourses on race focus on manhood. Patricia Hill Collins elaborated on this approach in Black Feminist Thought (1990), where she contended that the voices of black poor women have been silenced by those of white middle-class men. In a similar vein, as noted by Belknap, Kimberlé Crenshaw, in her work "Demarginalizing the Intersection of Race and Sex" (1989), argued that "there is a tendency to treat race and gender as mutually exclusive categories of experience and analysis, with the result that law suits addressing discrimination are defined 'by white women's and black men's experiences'” (Belknap 1996: 17).

The double-oppression suffered by black women has also influenced their being left out of discourses on racial profiling even though they are one of the most overpoliced groups in US society (Ritchie 2017: 10). As political scientist Joy James puts it, the acknowledgement of women as targets of institutional and police violence "is an issue rarely raised in feminist explorations of women and violence or masculinist explorations of racism and policing" (in Kaba 2017: xiv). In this respect, Derrick Clifton highlighted, in a conscious nod to Crenshaw, that whilst “it's understandable why there's so much coverage of black men being killed by 


\section{Eva Puyuelo Ureña}

police, the relative exclusion of women from this topic should be cause for concern" (2015). Disregarding women from such discourses results in two further problems. On the one hand, it provides a wrong perception of the dimensions of racial profiling. The focus on black men being the only targets of racist violence fails to account for the magnitude of the problem, as the high proportion of victims constituted by black women and girls, as well as of gender non-conforming individuals, is left out of the analysis. On the other hand, the focus on black men also silences discriminatory policing practices black women are particularly subject to, such as strip-searches and other forms of abusive frisking, sexual fondling, or rape, even if women are pregnant or menstruating (Ritchie 2017: 51-59). Both black women's racial profiling and their susceptibility to sexual harassment conceal a less obvious form of oppression - the underexamination, and often total invisibility, of black women who have been victims of racism and sexism ${ }^{7}$ in broader discourses on mass incarceration and police brutality. Andrea Ritchie elaborates on the gravity of this situation when she claims that

Most people easily recognize the names Trayvon Martin and Eric Garner, while Charleena Lyle's death is quietly put aside after a brief burst of press. Searching "Eric Garner" in Google yields news stories up to just two days ago detailing the family's wrongful death settlement. A Google search of Charleena, who died just this summer, yields only initial reports of her death. She was shot in front of her children by the police responding to her 911 call reporting a possible burglary. She was pregnant. (In Berrett 2017)

Activist and organizer Mariame Kaba has named the exclusion of black women from public discourses on racist violence "racialized gendered violence" (2017: xi).

Whilst Ta-Nehisi Coates writes extensively about the blatant violence the black body is exposed to, he does not provide in-depth descriptions either about black women being subject to sexual harassment or about black women being usual victims of policing. About the former he only writes that "the women around you must be responsible for their bodies in a way that you never will know" (Coates 2015: 71, emphasis added). There is no other instance in which this issue is brought up even though "sexual abuse is the second most reported form of police misconduct after the use of excessive force" (Bennett 2015). Many critics have been taken aback by his extremely brief analysis of the ways in which black women's experiences of policing are shaped by sexual harassment, pointing out that "it feels odd for a narrator who is otherwise insatiably curious" (Bennett 2015, emphasis added). Nonetheless, even if lingering on the margins of the story, black women's proneness to experiencing sexual harassment as a form of racial domination is there indeed. Something similar occurs with Coates's representation of black women ending up dead, injured or unfairly arrested after an encounter with law enforcement officers. In the initial pages of the text, Coates confesses to his son that 


\section{Racialized Gendered Violence(s) in Ta-Nehisi Coates}

I am writing to you because this was the year you saw Eric Garner choked to death for selling cigarettes; because you know now that Renisha McBride was shot for seeking help, that John Crawford was shot down for browsing in a department store. And you have seen men in uniform drive by and murder Tamir Rice, a twelve-yearold child whom they were oath-bound to protect. And you have seen men in that same uniforms pummel Marlene Pinnock, someone's grandmother, on the side of a road. (2015: 9, emphasis added)

Black women are thus named as victims of profiling at the beginning of the story, where Coates highlights the deaths of Renisha McBride, a 19-year-old who was shot dead when she knocked at a neighbor's house seeking for help after having had a car accident, and Marlene Pinnock, a homeless woman pulled over and beaten by a California Highway Patrol officer. At other points in the text, Coates also strives to raise awareness of the vulnerability of both black boys and black girls by using the generic children, and on very few occasions he does so by maintaining both masculine and feminine nouns and pronouns, as when he claims that "all my life I'd heard people tell their black boys and black girls to 'be twice as good'" (2015: 90-91, emphasis added), and that "the story of a black body's destruction must always begin with his or her error" (6, emphasis added). Nonetheless, his attempts to include women's experiences as part of the discourses on blackness and violence have often been considered few and problematic. In the last pages of the book Coates turns to the use of the exclusive son, which hampers, on the one hand, the possibility of black women being acknowledged as victims of policing and, on the other, the possibility of black women empathizing with and seeking answers to their own experiences in Coates's story. Nonetheless, in Coates's own words, this rather masculinized perspective could not be otherwise, as Between the World and $M e$ is the story of a black man telling his black son how to survive within the rampant racism that permeates US society. In a conversation with Isaac Chotiner, Coates claimed that "I understand that it is the male experience and I am a male writing the book. I don't know how to remedy that" (in Chotiner 2015).

Particularly troubling is the last chapter, which comprises an interview with Mabel Jones, Coates's dead friend's mother. ${ }^{8}$ After some initial reflections on the ways Mabel is coping with the killing of her son, the conversation leans towards more personal questions, and Coates soon notes that "she [Mabel] was intensely worried about her daughter bringing a son into America, because she could not save him, she could not secure his body from the ritual violence that claimed her son" (2015: 144). Two ideas can be inferred from his words. First of all, the fact that she does not seem to be worried about her daughter but about her daughter giving birth to a boy reiterates that black women are not considered victims of racial profiling, mass incarceration, nor of police violence (Bennett 2015). Second, the fact that her daughter is thus only considered a mother birthing a child reveals the extent to which 


\section{Eva Puyuelo Ureña}

black women are secluded into oppressive categories of identity. In so writing, Coates seems to be contending that black women are not vulnerable for being black or for being women, but for having an affective relationship with black men.

The delicacy with which Coates talks about the women in the text, by and large, verges on idealization, so much so that even though they are often depicted "lovingly, almost ethereally, $[\ldots]$ they rarely appear as complicated, fully fleshed-out people" (Bennett 2015). When he focuses on revisiting his childhood and early adulthood, Coates adopts an awestruck, respectful, almost reverential tone to refer both to his grandmother, whom he describes as a strong and rough woman who had witnessed her two brothers and her husband being murdered, and his wife, whom he admires because of her bravery and smartness. Nonetheless, as well-intended as these portrayals of black women might seem at first sight, one could argue that they border on what Patricia Hill Collins called "negative controlling images of black womanhood" (1990: 10). Black women are always described in their relation to men in the story, and so they are never represented as independent women with responsibilities of their own, but rather as mothers, grandmothers, sisters, daughters, or wives. This portrayal, in turn, as I noted above when analyzing Mabel Jones's reaction to the killing of her son, and as Shani $\mathrm{O}$. Hilton convincingly argues, contributes to the normalization of black women's experiences as being about loving and mourning, when in fact they should also be about "protecting oneself from physical plunder. It's about trying to live free in a black body, just like a man" (2015). The notion that feelings of affection somehow only concern black womanhood is also underscored by Coates's positioning himself within the framework of hegemonic masculinity. Whilst he describes women as caring and warm-hearted towards their acquaintances, Coates confesses that he is stern and utterly incapable of showing his son any bit of affection. He justifies this by claiming that "that is because I am tied to old ways, which I learned in a hard house" (2015: 126) where the men, following Martin Ghaill's analysis of black masculinities and codes of behavior, ${ }^{9}$

were aware of the historical contradictions of black masculinity as a subordinated
masculinity, with the denial of the patriarchal privileges of power, control and
authority that are ascribed to the white male role. [...] Their adoption of
hypermasculine codes of contestation and resistance may be read as attempts to
challenge current white institutional practices that they see as attempting to
"emasculate them". (1994: 188)

As stereotypical as it might seem, it is Coates's wife who teaches him that loving his son would in no way increase his vulnerability as a black man. He notes, "we are entering our last years together, and I wish I had been softer with you. Your mother had to teach me how to love you- how to kiss you and tell you I love you every night" (2015: 126, emphasis added). 


\section{Visibility Matters: Exposing the Stories of Black Women and Racial Profiling}

At this point it is clear, then, that the experiences of black women as regards racial violence are downplayed and subsumed within the experiences of black men (Belknap 1996). Nonetheless, as Andrea Ritchie elaborates in Invisible No More, black women are pulled over and frisked at an identical rate as black men, and "the year before [Michael] Brown was killed, black women in Ferguson were subjected to traffic stops more frequently than any other motorist" (2017: 10). She moves on to contend that the disproportionate rates of incarceration of black women are usually eclipsed by the number of black men being imprisoned although, as illustrated in the report Overlooked: Women and Jails in an Era of Reform, "the number of women [of color] in jail nationwide is growing at a faster rate than any other incarcerated population" (Swavola, Riley, and Subramanian 2016: 6). ${ }^{10}$ Similarly, even though black women are not portrayed as mortal victims of policing, they are in fact the second largest group in the population mostly affected by it, second only to black men. The research conducted by Mapping Police Violence reveals that a total of 102 black women were killed by police officers in 2015 .

Despite the alarming rates of black women being arrested or killed, not many of their stories make it into headlines and public consciousness. Renisha McBride and Marlene Pinnock, mentioned by Coates at the beginning of his text, are two of the few women whose fatal experiences with law enforcement caught national attention. A similar case is Mya Hall's, whose death acquired greater visibility after the first reports appeared in newspapers months after she was murdered. On March 30, 2015, black transgender woman Mya Hall, 27, and her 20-year-old friend Brittany Fleming were driving a stolen car around Baltimore when they took a wrong turn and ended up trespassing on the Baltimore Headquarters of the NSA. Authorities opened fire against her although "wrong turns at that particular exit are an extremely frequent occurrence" (Romano 2015). Instead, she was "immediately shot as a potential terrorist" (Ritchie 2017: 65). The brutality of Mya Hall's murder, however, is not restricted to the unethical reaction of law-enforcement officers (Hermann 2015). Her murder was absent from the media for months, and the situation did not get any better when national news decided to shed light on her story, as she was misgendered and constructed as mentally deranged (Teeman 2017). Moreover, many published articles proved to be transphobic in that they "describe[d] Hall and Fleming as 'men dressed as women', a revelation which [the articles] referred to as a 'shocking twist'. [They] also described the street scene where Hall and Fleming worked as a 'choreography of clichés', focusing on the high heels, short shorts, and heavy makeup of the women" (Romano 2015). Their operating outside hetero-patriarchal roles was privileged over the racist misconduct of the agents. 


\section{Eva Puyuelo Ureña}

Sandra Bland's murder was also considered critical in the fight for the visibility of black women victims of racial profiling, so much so that it ended up triggering the creation of the \#SayHerName campaign. Bland was pulled over by police officer Brian Encinia in Hempstead, Texas, on July 10, 2015. He asked her to put out her cigarette, to which she replied that she was in her car and that she had the right to smoke if she wanted to (K. Davis 2018: min. 00:16:13). The encounter soon escalated, and the officer decided to arrest Bland for allegedly assaulting him. ${ }^{11}$ She was afterwards put in custody, and her body was found in her cell three days later, on July 13, 2015. Her death was ruled a suicide by hanging, a fact later undermined by the autopsy results (Botelho and Ford 2015). According to Andrea Ritchie, Bland's story, just like McBride's, Pinnock's, or Hall's, stands out from many others because of its particularities. In her own words, "there are many reasons Sandra's story gained national attention when so many women's [stories] had not" (2017: 9), such as the videos she posted on social networking sites before being arrested, the recording of the officer's car dashcam showing her arrest, or her alleged suicide whilst she was in police custody. After making it into public consciousness right when her body was found in jail, her story soon turned into a national matter for different reasons, such as the strange circumstances surrounding her death, which evidenced the abuses black individuals might be exposed to, or the lack of surveillance of black people in county jails and other facilities, where they would be locked up and not checked on for hours (K. Davis 2018: min. 01:26:43). Sandra Bland thus became one of the first female victims of police brutality to trigger so much social unrest. As Hannah Bonner puts it in the documentary Say Her Name: The Life and Death of Sandra Bland, "when Sandra died, we had not seen a woman's name have that staying power that we had seen with Michael Brown, Tamir Rice, Trayvon Martin. Women had died but we had not continued to say their names" (in K. Davis 2018: min. 00:40:21).

On a more positive note, it is clear that significant changes started occurring after Bland's death. As mentioned above, the acknowledgement of the racist experiences endured by women of color such as Rekia Boyd or Sandra Bland herself, amongst thousands of others, has been critical to the development of the \#SayHerName campaign, which was set up by the African American Policy Forum (AAPF) in early 2015.12 Later that year a report entitled "\#SayHerName: Resisting Police Brutality Against Black Women" was published with the intention "to serve as a resource for the media, organizers, researchers, policy makers, and other stakeholders to better understand and address black women's experiences of profiling and policing" (Crenshaw and Ritchie 2015). The movement soon turned into a national phenomenon that brought, through demonstrations, activist campaigns, and public exhibits, the status of the visibility of the murders 


\section{Racialized Gendered Violence(s) in Ta-Nehisi Coates}

of black women and girls up to that of black men. As part of a series of acts organized by the movement, the art exhibit Blood at the Root: Unearthing the Stories of State Violence against Black Women opened in 2015. Cohosted by women vocal in the denouncement of the situation such as Ayanna Banks-Harris, Rachel Caidor, Mariame Kaba, Deana Lewis, Andrea Ritchie, and Ash Stephens, Blood at the Root, in their own words,

focuses our attention on the fact that all \#BlackWomensLivesMatter and all \#BlackGirlsLivesMatter. Relying on various artifacts, the curators narrate the experiences and resistance of black women and girls - trans and non-trans- who have been brutalized, imprisoned and killed by the state and its agents. (2015)

The exhibit featured artistic works that elaborated on the long history of silencing which black women have endured for being both black and women. Also, drawings, artistic pictures, and spray-painted portraits of Rekia Boyd, Joanne Little, or Paris Knox, amongst many others, sought to honor their lives and urged visitors to keep fighting towards the inclusion of black women in discourses on systemic violence. ${ }^{13}$ Andrea J. Ritchie, together with Kimberlé Crenshaw and many others, has also extensively ${ }^{14}$ elaborated on the need for black women to be seen as victims of police brutality and other expressions of racialized gendered violence. ${ }^{15}$ Amongst other theorists who have engaged in the fight for the public recognition of women as being subject to racial profiling we must also highlight Angela Y. Davis, who published in 2003 Are Prisons Obsolete?, Michelle Alexander, with The New Jim Crow (2010), and Patrisse Khan-Cullors, whose autobiography and Black Lives Matter memoir When They Call You a Terrorist was published in early 2018. ${ }^{16}$ Besides the progress achieved in academic scholarship and research, demonstrations and other activist campaigns are also contributing to the expansion of the movement. On June 27, 2015, filmmaker Bree Newsome protested against the exclusion of black women from public discourses on racism by removing the Confederate flag outside the South Carolina Statehouse. After being arrested, Newsome underscored that "it was decided that this role should go to a black woman and that a white man should be the one to help her over the fence as a sign that our alliance transcended both racial and gender divides. I did it for all the fierce black women on the front lines of the movement and for all the little black girls who are watching us" (in Tillet 2015, emphasis added).

\section{Conclusion}

As much as a necessary claim for a reconsideration of policing and racism as Between the World and $\mathrm{Me}$ is, the memoir indeed lacks a thorough analysis on 


\section{Eva Puyuelo Ureña}

the ways in which black women's experiences are also framed by racial profiling. The exclusion of black women from discourses on policing, in turn, has proved to be overly unsettling, not only because it limits the dimensions of the problem to the experiences lived by black men, but also because it contributes to a long history in which black women's voices have been silenced from mainstream narratives. It does not matter whether black girls are six times more likely to be suspended from high school than their male counterparts or twelve times more than their female white counterparts (Crenshaw 2015); nor whether black women are subject to traffic stops at a higher rate than any other racial or gender group (Ritchie 2017); nor whether the black women's prison population is growing at a faster rate than any other prison population (A.Y. Davis 2003); nor whether black women are the second largest group more prone to being killed as a result of an encounter with the police (Ritchie 2017). And the fact that texts that have the print-run and success of Between the World and Me provide such a limited description of the intersection between sexism, racial profiling, and policing, does not make it any better. In the view of Shani O. Hilton, the fact that most readers of the best-selling memoir will not ever wonder about the displacement of women from the main point of the story contributes to a normalization of men's bodies being the only targets of racism- yet another of the most silent and harmful forms of violence exerted upon black women's bodies (2015).

Andrea Ritchie's theory that only black women's stories with particularities stand out is being undermined bit by bit, as most of them are nowadays making it into public consciousness owing to the increasing number of organizations and social movements in favor of the visibility of black women victims of biased policing. The consolidation of coalitions such as \#SayHerName, \#BlackGirlsMatter or \#BlackWomenMatter, amongst many others, has led to a general acknowledgement of the extent to which black women are overpoliced but underprotected. In a similar vein, many artistic projects, including art exhibits, film screenings or literary conferences have engaged in the fight for the visibility of black women as victims of policing. But even if we are on the right track, there is still much work to do. In the last few years, black women have not ceased to resist and challenge racial profiling, but neither have they stopped being assaulted and killed at alarmingly high rates. Including them in efforts to address racial profiling is critical not only to broaden our understanding of contemporary forms and experiences of racism but also to turn a deafening silence into a rallying cry. ${ }^{17}$ 


\section{Notes}

1. This phrase is taken from the title of the first report issued by the \#BlackGirlsMatter campaign in 2015. For more information see Crenshaw 2015.

2. There has been much debate as to what literary genre Between the World and Me falls into. In this article the book is considered a memoir, as it retells the story of the author's childhood, youth and young adulthood, including his opinions and perceptions of the events he has been witnessing for years.

3. Numbers obtained from the online database Mapping Police Violence (<www.mappingpoliceviolence.org $>$ ).

${ }^{4}$. It is in fact Samori's reaction to the acquittal of Michael Brown's murderer that makes Coates start writing the text. That moment is described as follows: "[T]he men who had left [Michael Brown's] body in the street like some awesome declaration of their inviolable power would never be punished. It was not my expectation that anyone would ever be punished. But you were young and still believed. [...] You went into your room, and I heard you crying" (2015: 11).

5. In the memoir he claims that "murder was all around us and we knew, deep in ourselves, in some silent space, that the author of these murders was beyond us, that it suited some other person's ends" (2015: 114 , emphasis added).

6. My use of the word women is inclusive of black transgender women, even if they are not the focus of my study. However, I would like to highlight the precarity and vulnerability affecting the lives of black transgender women. Black transgender victims of policing are notably absent from headlines and national reports on police brutality even if, according to a report published by the Human Rights Campaign and the Trans People of Color Coalition in 2017, "since January 2013, [...] at least 102 transgender people [...] were victims of fatal violence. At least 87 were transgender people of color" (Lee 2017: 34). However, because of a systematic refusal to acknowledge the gender identities of the victims, it is difficult to "track [these] cases as they occur" (33). In his essay "Black Rights, Gay Rights: Civil Rights" (1999), professor Devon W. Carbado contends that the refusal to standardize black transgenderism in contemporary society derives from a "mythologized historiography" that, in the opinion of gay rights activist Marlon Riggs and many others, has normalized the racialization of transgenderism as white and "the ontological conception of blackness as [cisgender]" (in Carbado 1999: 284). Because of the previous assertion, these individuals' bodies are perceived as "problem bodies" (Ritchie 2017: 53). For more information on the experiences of black transgender women and policing, see Carbado 1999, Lee 2017, and Ritchie 2017.

7. As Andrea Ritchie suggests, racial profiling and sexual harassment are interrelated. She claims that often blackness is used as a pretext to exert sexual abuse on black women (2017).

${ }^{8}$. Mabel Jones's son, Prince Jones, was killed during an encounter with a police officer. Coates had met Prince Jones at Howard University, and they had become close friends. After learning that the Prince George's County Police had murdered somebody, Coates saw in a newspaper that the victim had been Prince Jones. He describes it in the following way: "I saw him there. He was dressed in his formal clothes, as though it were his senior prom, and frozen in the amber of his youth. His face was lean, brown, and beautiful, and across that face, I saw the open, easy smile of Prince Carmen Jones" (2015: 77). After telling us that the officer who killed Prince Jones had lied and been accused of misconduct many times before, Coates notes, "the officer had been dressed like an undercover drug dealer. He'd been sent out to track a man whose build was five foot and 250 pounds. We know from the coroner that Prince's body was six foot three and 211 pounds. [...] The officer confronted Prince with his gun drawn, and no badge. [...] This officer, given maximum power, bore minimum responsibility. He was charged with nothing. He was punished by no one. He was returned to his work" (88). 


\section{Eva Puyuelo Ureña}

9. Ghaill's contention clearly draws from the canonical study on black masculinities conducted by Mercer and Julien (1988).

10. According to Angela Y. Davis, the invisibilization of black women in discourses on racial profiling and mass incarceration owes to the fact that their offenses are usually related to mental illness rather than felony. In her own words, "deviant men have been constructed as criminal, while deviant women have been constructed as insane" (2003: 66). In a similar way, the oppression that black women face when imprisoned is also overlooked. Davis contends that while black men "experience a perilous continuity in the way they are treated in school [...], in the streets [...] and in prison [...], for women, the continuity of treatment from the free world to the universe of the prison is even more complicated, since they also confront forms of violence in prison that they have confronted in their homes and intimate relationships. The criminalization of black [...] women includes persisting images of hypersexuality that serve to justify sexual assaults against them both in and outside of prison" (79-80).

11. This can be contested after watching both a bystander's video displaying her arrest and the officer's car dashcam recording of that moment. Both are available in K. Davis 2018.
12. Prior to that there were also many attempts to include black women and girls in discourses on race, such as the 2014 “\#WhyWeCan'tWait campaign, [which] argued against the exclusion of African American girls from President Obama's singular racial-justice initiative, My Brother's Keeper" (Tillet 2015).

13. For more information on the exhibit visit <https://bloodatrootchicago. wordpress.com $>$.

${ }^{14}$. See her books Queer (In)justice: The Criminalization of LGBT People in the United States (2011), Say Her Name: Resisting Police Brutality Against Black Women (2015), a report coedited with Kimberlé Crenshaw (Crenshaw and Ritchie 2015), or the most recent Invisible No More (2017).

15. As mentioned above, police brutality must be seen as one expression of racialized gendered violence, as in most cases discriminatory enforcement implies different forms of sexual abuse. For more information see A.Y. Davis 2003 and Ritchie 2017.

16. This is just a limited selection of the works that engage in the movement, but of course there are many others I cannot include here for reasons of space.

17. This article is part of the research funded by the Spanish Government and European Union under an FPU Grant (Grant Number FPU15/00741).

\section{Works Cited}

Alexander, Michelle. 2010. The New Jim Crow: Mass Incarceration in the Age of Colorblindness. New York: The New Press.

Alexander, Michelle. 2015. "Ta-Nehisi Coates's Between the World and Me". The New York Times (August 17). <https://www.nytimes. com/2015/08/17/books/review/ta-nehisicoatesbetween-the-world-and-me.html>. Accessed February 15, 2019.

Banks-Harris, Ayanna, Rachel CAIDOR, Mariame KaBA, Deana LeWIS, Andrea RITCHIE and Ash
Stephens. 2015. "About". Blood at the Root: Unearthing the Stories of State Violence against Black Women. <https://bloodatrootchicago. wordpress.com>. Accessed February 11, 2019.

BelknAP, Joanne. 1996. The Invisible Woman. Belmont: Wadsworth Publishing.

BennetT, Brit. 2015. "Ta-Nehisi Coates and a Generation Waking Up". The New Yorker (July 15). $<$ https://www.newyorker.com/culture/cultural -comment/ta-nehisi-coates-and-a-generation -waking-up>. Accessed February 2, 2019. 


\section{Racialized Gendered Violence(s) in Ta-Nehisi Coates}

Berrett, Jenni. 2017. "An Interview with Andrea Ritchie, Activist and Author of Invisible No More." Ravishly (September 8). <https://ravishly. com/people-we-love/interview-andrea-ritchieactivist-author-invisible-no-more>. Accessed January 7, 2019.

BотеLho, Greg and Dana Ford. 2015. "Sandra Bland's Death Ruled Suicide by Hanging". CNN (July 24). <https://edition.cnn.com/2015/07/23/ us/sandra-bland-arrest-death-main/>. Accessed December 24, 2018.

Carbado, Devon W. 1999. "Black Rights, Gay Rights: Civil Rights". Black Men on Race, Gender, and Sexuality. NewYork: NewYork U.P.

CHOTINeR, Isaac. 2015. "A Conversation with Ta-Nehisi Coates". Slate (July 13). <https://slate. com/culture/2015/07/ta-nehisi-coates-thebetween-the-world-and-me-author-oncharleston-obama-and-harper-lee.html>. Accessed March 3, 2019.

Clifton, Derrick. 2015. “BlackWomen Are Getting Killed by the Police Too - So Why Aren't More People Discussing It?" The Mic Network (May 11). <https://mic.com/articles/117228/black-womencontinue-getting-killed-by-police-why-aren-tmore-people-discussing-it\#.B0xlbW98i>. Accessed December 31, 2018.

COATES, Ta-Nehisi. 2014. "The Case for Reparations". The Atlantic (June). <https://www. theatlantic.com/politics/archive/2014/06/thecase-for-reparations-a-narrative-biblio graphy/372000/>. Accessed January 4, 2019.

COATES, Ta-Nehisi. 2015. Between the World and Me. Melbourne:Text Publishing Company.

Coluins, Patricia Hill. 1990. Black Feminist Thought. New York: Routledge.

Crenshaw, Kimberlé. 1989. “Demarginalizing the Intersection of Race and Sex". University of Chicago Legal Forum 1 (8): 139-167.

Crenshaw, Kimberlé. 2015. Black Girls Matter: Pushed Out, Overpoliced, and Underprotected. New York: The African American Policy Forum. $<$ https://static1.squarespace.com/static/53f20d 90e4b0b80451158d8c/t/555e2412e4b0bd5f4da5 d3a4/1432232978932/SAYHERNAME+Social+ Media+Guide.compressed.pdf $>$. Accessed December 12, 2018.

Crenshaw, Kimberlé and Andrea Ritchie. 2015. Say Her Name: Resisting Police Brutality against Black Women. New York: The African American Policy Forum. <https://static1. squarespace.com/static/53f20d90e4b0b8045 1158 d 8 c/t / 555 e 2412 e 4 b 0 bd 5 f 4 d a 5 d 3 a 4/ 1432232978932 / S AYHER N AME +Social+Media+Guide.compressed.pdf>. Accessed December 12, 2018.

Davis, Angela J. 2017. Policing the Black Man: Arrest, Prosecution and Imprisonment. New York: Vintage Books.

Davis, Angela Y. 2003. Are Prisons Obsolete? New York: Seven Stories Press.

Davis, Kate. 2018. Say Her Name: The Life and Death of Sandra Bland. HBO.

Duvernay, Ava. 2016. 13th. Netflix.

GHAILL, Martin. 1994. "The Making of English Black Masculinities". In Brod, Harry and Michael Kaufman (eds.) Theorizing Masculinities. California: Sage Publications: 183-199.

Goodman, Amy. 2015. “Ta-Nehisi Coates on Police Brutality: 'The Violence is Not New, It's the Cameras That are New'." Democracy Now! Independent Global News (November 27). $<$ https://www.democracynow.org/2015/11/27/ ta_nehisi_coates_on_police_brutality $>$. Accessed January 10, 2019.

Hermann, Peter. 2015. “Baltimore's Transgender Community Mourns One of Their Own, Slain by Police". The Washington Post (April 3). <https:// www.washingtonpost.com/local/crime/ baltimores-transgender-community-mourns-oneof-their-own-slain-by-police/2015/04/03/2f657da4d88f-11e4-8103-fa84725dbf9d_story.html?utm term=.82812d6246d5>. Accessed January 7, 2019.

HILTON, Shani O. 2015. "The Black Experience Isn't Just About Men". BuzzFeed (July 10). <https://www.buzzfeed.com/shani/betweenthe-world-and-she?utm_term=.ep8IzJwppd\#. ysr8wODkkz>. Accessed December 17, 2018.

Hull, Gloria Akasha, Patricia Bell Scott and Barbara Sмıтн. (eds.) (1982) 2015. All the Women Are White, All the Blacks Are Men, But Some of Us Are Brave. New York:The Feminist Press at the City University of New York.

KABA, Mariame. 2017. "Foreword". Invisible No More: Police Violence against Black Women and Women of Color. Boston: Beacon Press. 


\section{Eva Puyuelo Ureña}

Khan-Cullors, Patrisse. 2018. When They Call You a Terrorist: A Black Lives Matter Memoir. New York: St. Martin's Press.

LeE, Mark. 2017. “A Time to Act: Fatal Violence against Transgender People in America 2017". Trans People of Color Coalition and Human Rights Campaign Foundation. <http:// assets2.hrc.org/files/assets/resources/A_Time_ To_Act_2017_REV3.pdf>. Accessed December $12,2018$.

LoWERY, Wesley. 2017. They Can't Kill Us All: The Story of Black Lives Matter. London: Penguin Books.

Mauer, Marc. 1990. Young Black Men and the Criminal Justice System: A Growing National Problem. Washington D.C.: The Sentencing Project.

Mercer, Kobena and Isaac Julien. "Race, Sexual Politics and Black Masculinity: A Dossier". Male Order: Unwrapping Masculinity. London: Lawrence \& Wishart: 97-164.

MilleR, Monica R. 2016. "Black Lives Matter and the Mo(ve)ment of Black America". Ausgabe. $<$ https://fiph.de/veroeffentlichungen/journale/ cover-downloads/fiph_026_RZ_Journal_Aus gabe_28_Monica_Miller.pdf?m=1477661803\& >. Accessed January 9, 2019.

RamBsy II, Howard. 2016. "The Remarkable Reception of Ta-Nehisi Coates". African American Review 49 (3): 196-204.

RITCHIE, Andrea J. 2011. Queer (In)justice: The Criminalization of LGBT People in the United States. Boston: Beacon Press.

RitchiE, Andrea J. 2017. Invisible No More: Police Violence against Black Women and Women of Color. Boston: Beacon Press.

Romano, Aja. 2015. “A Transgender Woman Was Shot in Baltimore and no One is Talking about It". The Daily Dot (April 30). <https:// www.dailydot.com/irl/transgender-sexworker-mya-hall-death-nsa/>. Accessed December 17, 2018.

SANDHU, Sukhdev. 2015. "Between the World and Me by Ta-Nehisi Coates Review-A Now
Exalted Writer and Spokesman for Black America". The Guardian (October 8). <https:// www.theguardian.com/books/2015/oct/08/ between-the-world-and-me-sukhdev-sandhureview>. Accessed February 21, 2019.

SAucier, Khalil and Tryon P. Woods. 2016. Conceptual Aphasia in Black: Displacing Racial Formation. New York: Lexington Books.

SHARPE, Christina. 2016. In the Wake: On Blackness and Being. Durham: Duke U.P.

SMITH, Clint. 2015. "How to Raise a Black Son in America". Ted Talks. <https://www.ted.com/ talks/clint_smith_how_to_raise_a_black_son_ in_america/transcript>. Accessed February 17, 2019.

Swaine, Jon, Oliver Laughland, Jamiles LaRTEY and Ciara McCARTHY. 2015. "Young Black Men Killed by US Police at Highest Rate in Year of 1.134 Deaths". The Guardian (December 31). $<$ https://www.theguardian.com/us-news/2015/ $\mathrm{dec} / 31 /$ the-counted-police-killings-2015-youngblack-men>. Accessed January 21, 2019.

Swavola, Elizabeth, Kristine RILEY and Ram Subramanian. 2016. Overlooked: Women and Jails in an Era of Reform. New York: Vera Institute of Justice. <http://www. safetyandjusticechallenge.org/wp-content/ uploads/2016/08/overlooked-women-in-jailsreport-web.pdf>. Accessed September 23, 2020.

TeEman, Tim. 2017. "Why Are So Many Transgender Women of Color Being Killed in America?" The Daily Beast (April 8). <https:// www.thedailybeast.com/why-are-so-manytrans-women-of-color-being-killed-inamerica>. Accessed January 7, 2019.

Tillet, Salamishah. 2015. “Female Visibility Matters". The New York Times Magazine (August 7). <https://www.nytimes.com/2015/ 08/07/magazine/female-visibility-matters. html>. Accessed January 4, 2019.

WARD, Jesmyn. 2017. “Raising a Black Son in the US". The Guardian (October 28). <https:// www.theguardian.com/lifeandstyle/2017/ oct/28/raising-black-son-america>. Accessed December 11, 2018. 